\title{
Bly Creek ecosystem study - nitrogen exchange within a euhaline salt marsh basin of North Inlet, South Carolina*
}

\author{
Thomas G. Wolaver ${ }^{1}$, Gary J. Whiting ${ }^{2}$, Richard F. Dame ${ }^{1}$, Thomas M. Williams ${ }^{3}$, \\ John D. Spurrier ${ }^{4}$
}

\author{
${ }^{1}$ Belle W. Baruch Institute for Marine Biology and Coastal Research, University of South Carolina, Columbia, South Carolina \\ 29208, USA \\ ${ }^{2}$ Langley Research Center, N.A.S.A., MS483, Hampton, Virginia 23665, USA \\ ${ }^{3}$ The Belle W. Baruch Forest Science Institute, Clemson University, Georgetown, South Carolina 29442, USA \\ ${ }^{4}$ Department of Statistics, University of South Carolina, Columbia, South Carolina 29208, USA
}

\begin{abstract}
Nitrogen exchange within the Bly Creek basin (North Inlet, South Carolina, USA) was studied during 34 tidal cycles between 20 June 1983 and 19 June 1984 . Estimates of tidally mediated transport were made along with annual estimates of nitrogen input to the basin via streamwater, groundwater, and rainwater. Within the basin, effects of the vegetated marsh, oyster reef community, and the tidal creek on material transport were assessed. There was a small, but statistically insignificant $(\alpha=0.05) \mathrm{NH}_{4}^{+}$export from the basin through the tidal creek of $433 \mathrm{~kg} \mathrm{~N} \mathrm{yr}^{-1}\left(0.65 \mathrm{~g} \mathrm{~N} \mathrm{~m}^{-2} \mathrm{yr}^{-1}\right)$; inputs into the basin via streamwater, groundwater, and rain totalled $78 \mathrm{~kg} \mathrm{NN_{4 } +}-\mathrm{N} \mathrm{yr}^{-1}$. $\mathrm{The}^{-} \mathrm{NH}_{4}^{+}$ mass balance suggests the basin is not a source or a sink for this constituent to the surrounding estuary. However, since the vegetated marsh surface imports ca $1500 \mathrm{~kg} \mathrm{NH}_{4}^{+}-\mathrm{N} \mathrm{yr}^{-1}$, the tidal creek subsystem must act as a source. It is suggested that remobilization of $\mathrm{NH}_{4}{ }^{+}$within the tidal creek water column and/or benthic community produces the ammonium necessary to satisfy the input of this constituent to the vegetated marsh. There was also a small, insignificant import of nitrate + nitrite into the basin through the tidal creek of $158 \mathrm{~kg} \mathrm{~N} \mathrm{yr}^{-1}\left(0.23 \mathrm{~g} \mathrm{~N} \mathrm{~m}^{-2} \mathrm{yr}^{-1}\right)$. The vegetated marsh is capable of removing all the nitrate + nitrite potentially imported into this system via tidal water, streamwater, groundwater, and rain. There was a significant $(\alpha=0.05)$ dissolved organic nitrogen (DON) export from the basin of $7782 \mathrm{~kg} \mathrm{Nyr}{ }^{-1}$ or $11.7 \mathrm{~g} \mathrm{~N} \mathrm{~m}^{-2} \mathrm{yr}^{-1}$, whereas there was a statistically insignificant import of particulate

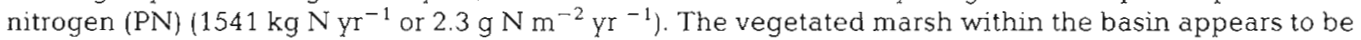
the main source of DON material to the basin as a significant amount of DON was exported both during tidal inundation and via runoff during tidal exposure. Due to the lack of statistical significance in the tidally mediated PN flux, it is difficult to state whether the basin is a source or sink for this constituent. However, a negative association between tidally mediated PN flux and maximum tidal height suggests that the marsh surface is important in removing PN during high tide conditions.
\end{abstract}

\section{INTRODUCTION}

To test the 'Outwelling Hypothesis' (Odum 1968, Nixon 1980) nitrogen transport studies have been conducted in many marsh-estuarine systems (Axelrad 1974, Heinle \& Flemer 1976, Valiela et al. 1978, Woodwell et al. 1979, Dame et al. 1986). The results from these research efforts suggest that $\mathrm{NH}_{4}{ }^{+}, \mathrm{DON}$, and $\mathrm{PN}$ are generally exported through tidal creeks into the

\footnotetext{
- Contribution No. 716 of the Belle W. Baruch Institute for Marine Biology and Coastal Research
}

adjacent water body while nitrate is imported. Since initial speculation by Teal (1962), the vegetated marsh surface has been considered to be the source of the materials outwelled through tidal creeks. Denitrification and $\mathrm{N}_{2}$-fixation rates in salt marsh sediments have been used to explain import and export of nitrate and ammonium respectively (Nixon 1980), whereas the source of exported dissolved organic material (DOC in particular) has been attributed to leaching from live and dead Spartina (Gallagher et al. 1976, Turner 1978, Pakulski 1986) or diffusion from marsh sediments (Pomeroy et al. 1977). Correspondingly, the source of 
the outwelled PN was assumed to be associated with marsh macrophyte productivity (Valiela et al. 1978). However, a flume study on a mesohaline marsh in Virginia (Wolaver et al. 1983, Wolaver \& Zieman 1984) showed that this subsystem is a sink for particulate nitrogen, $\mathrm{NH}_{4}{ }^{+}$, and $\mathrm{DON}$, and a small source for nitrate. The results from the research discussed above suggest that there is no clear understanding of which subsystems (vegetated marsh, tidal creek, invertebrate community, etc.) within the marsh-estuarine system are controlling nitrogen flux magnitude and direction or what specific mechanisms are involved.

To address this problem, the Bly Creek Ecosystem Study' evaluated material processing in a salt marshestuarine system by estimating contemporaneously (1) the major fluxes into and out of the system (tidally mediated exchange, streamwater, groundwater, and rain) and (2) the contribution of the major subsystems (vegetated marsh, oyster reef, and tidal creek) to material transport. In this article we will discuss the tidally mediated transport of nitrogen and evaluate the aqueous nitrogen mass balances for the Bly Creek basin, North Inlet, South Carolina, USA. These results will be then integrated with those from flume studies which were conducted on the vegetated marsh (Wolaver et al. 1985, Whiting et al. unpubl.) and oyster reef community (Dame et al. 1985, Dame et al. unpubl.).

\section{METHODS}

To study nitrogen exchange between the Bly Creek basin and the adjacent water body, material flux measurements were made at a transect across the only tidal creek within the system. The Bly Creek transect (BCT) was $53 \mathrm{~m}$ wide with a mean depth of $1.33 \mathrm{~m}$ at mean tide height and was located near the midpoint of the Bly Creek basin (Fig. 1). The vegetation within the basin is dominated by the various growth forms of Spartina alterniflora. The area of the basin is 660000 $\mathrm{m}^{2}$ of which $532000 \mathrm{~m}^{2}$ are covered by vegetated salt marsh, and $128000 \mathrm{~m}^{2}$ by tidal creek channels including $1000 \mathrm{~m}^{2}$ of oyster reef community.

Nitrogen concentration and velocity measurements were made at the BCT during 34 complete tidal cycles, every 11.8 d, between 20 June 1983 and 19 June 1984. This sampling schedule was chosen to obtain a representative range of lunar and diel periods over each season. Water samples were taken at one station in the middle of the BCT. One station was chosen following a detailed analysis of flows across the channel during a 2 tidal cycle calibration sampling (Kjerfve \& Wolaver 1988). These samples were collected at 2 depths (near bottom and mid water-column depth) once every hour for a full tidal cycle beginning at low tide. All water samples were placed immediately on ice in the field and were returned to the chemistry laboratory for processing within 2 h of collection. Initially, a $3 \mathrm{ml}$ aliquot was removed and stored (frozen) for total nitrogen (TN) determination. The rest of the sample was then filtered through a Whatman $4.7 \mathrm{~cm} G F / F$ filter with a $3 \mathrm{ml}$ subsample frozen for total dissolved nitrogen (TDN) analysis. Two other aliquots were removed from the filtered sample and preserved in phenol or mercuric chloride for ammonium and nitrate analyses, respectively. TN and TDN were determined by digesting the appropriate filtered and unfiltered samples via the alkaline persulfate technique (Glibert et al. 1977). In the digestion all the reduced forms of nitrogen were oxidized to nitrate. Subsequently, the $\mathrm{NH}_{4}{ }^{+}$and nitrate sample were analyzed using an Autoanalyzer II system [ammonium, Berthelot reaction (O'Brian \& Fiore 1962), Technicon industrial method $(154-71 \mathrm{~W})$; nitrate + nitrite, Griess reaction, Technicon industrial method (158-71W/A)]. Particulate nitrogen (PN) and dissolved organic nitrogen (DON) were calculated as follows:

$$
\begin{aligned}
\mathrm{PN} & =\mathrm{TN}-\mathrm{TDN} \\
\mathrm{DON} & =\mathrm{TDN}-\mathrm{NH}_{4}{ }^{+}-\left(\mathrm{NO}_{3}{ }^{-}+\mathrm{NO}_{2}{ }^{-}\right)
\end{aligned}
$$

Water velocities were measured at the same station and times as the collection of water samples but with a depth increment of $0.5 \mathrm{~m}$ from the tidal creek bottom to the water surface. These measurements were made with current crosses (Kjerfve 1982), with flow directions estimated using a surface streamer and compass. Instantaneous water discharge estimates through the BCT were made by decomposing the velocity vectors into an along-channel $u$-flow component (positive for ebb) and an across-channel $v$-flow component (positive toward the northern bank; Kjerfve et al. 1981, Kjerfve \& Wolaver 1988). A cubic spline was fitted to each individual vertical $u$-component velocity profile and 11 equidistant velocity values were interpolated. Each velocity was cross multiplied by the transect width and time-varying depth; the resulting product was summed over the total cross section to yield instantaneous discharge.

Instantaneous mass fluxes (IMF) were calculated by first spline-fitting the nitrogen concentration values similarly to the velocities. Then 11 interpolated nitrogen values were cross multiplied with the appropriate velocity, station width, and water depth, and summed over the cross section. IMF values for each sample period were then integrated over time to obtain the net flux per tidal cycle. This integration was accomplished by fitting the following sine-cosine model to the IMF values.

$$
\operatorname{IMF}(t)=\sum_{t=1}^{5} \alpha_{I} \sin \left(2 \pi t / \mathrm{P}_{t}\right)+\sum_{t=1}^{5} \beta_{I} \cos \left(2 \pi t / \mathrm{P}_{T}\right)+\varepsilon
$$



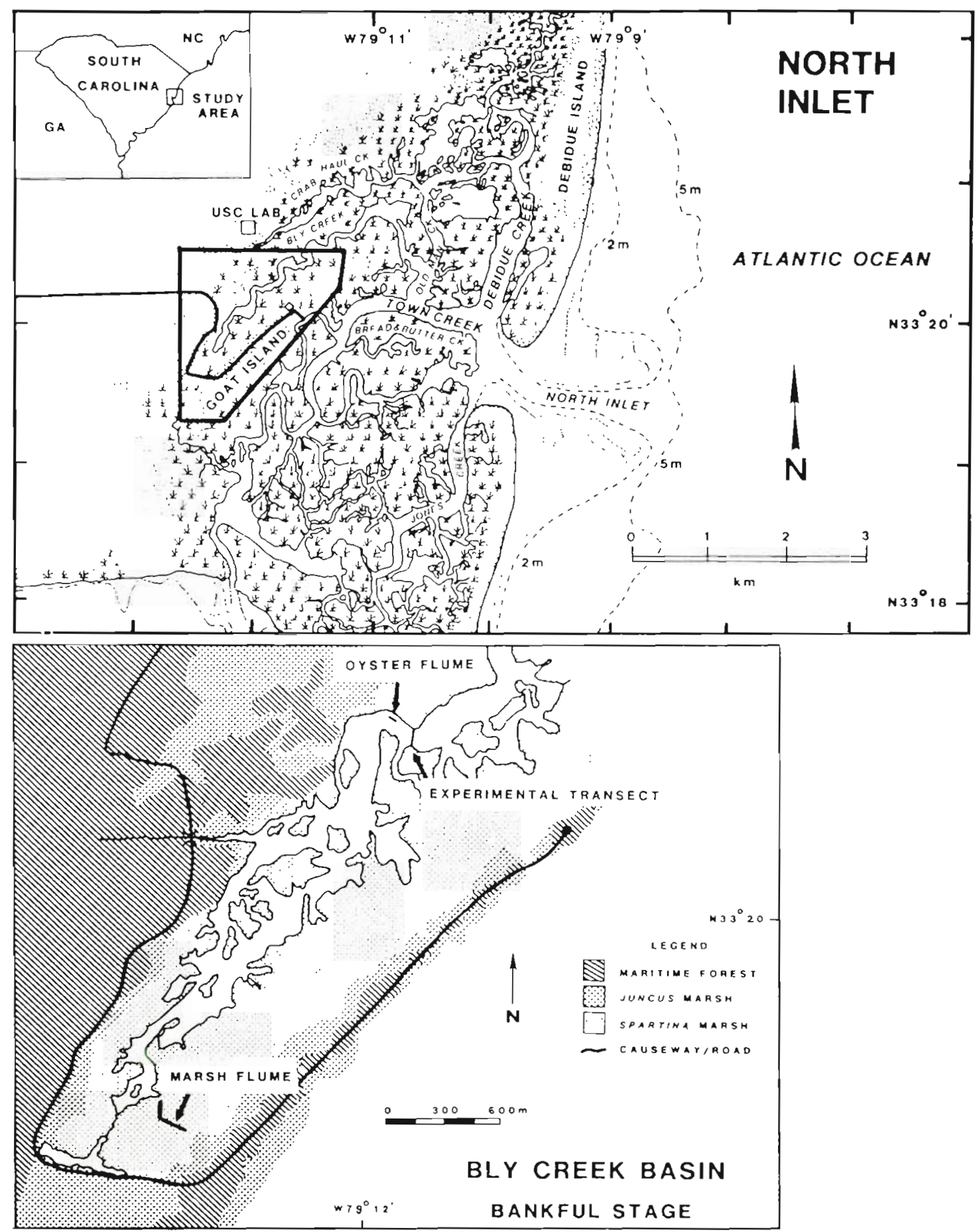

Fig. 1. Study site in South Carolina, USA

In fitting the model, periodicities of major tidal constituents (K1, M2, M4, M6) were selected with the corresponding periods $\mathrm{P}_{1}=24.86 \mathrm{~h}, \mathrm{P}_{2}=12.42 \mathrm{~h}, \mathrm{P}_{3}=$ $6.21 \mathrm{~h}, \mathrm{P}_{4}=3.11 \mathrm{~h}$, and $\mathrm{P}_{5}=4.14 \mathrm{~h}$. In addition, $t=$ time (h) from an arbitrary starting time; $\alpha_{1} \ldots \alpha_{5}, \beta_{1} \ldots \beta_{5}=$ unknown parameters; $\varepsilon=$ a random error term. The model is similar to that used by Chrzanowski et al. (1982), Whiting et al. (1985), and Wolaver et al. (1985).

To estimate the seasonal and annual exchange of material through the BCT a set of 24 parameters (Table 1) were measured for each tidal cycle throughout the sampling year. We estimated the annual flux for the 
Table 1 Predictor variables used in stepwise regression analysis

\begin{tabular}{|c|c|}
\hline $\begin{array}{l}\text { Variable } \\
\text { name }\end{array}$ & Description \\
\hline TIDE & Maximum tidal height \\
\hline L1 TIDE & Maximum tidal height on previous cycle \\
\hline L2 TIDE & $\begin{array}{l}\text { Maximum tidal height on second previous } \\
\text { cycle }\end{array}$ \\
\hline RAIN & Rainfall on current cycle \\
\hline L1 RAIN & Rainfall on previous cycle \\
\hline L2 RAIN & Rainfall on second previous cycle \\
\hline R13 & $\begin{array}{l}\text { Sum of rainfall }\left(>1.27 \mathrm{~cm}_{\text {event }}{ }^{-1}\right) \text { during } \\
\text { tidal exposure over preceding } 8 \text { cycles }\end{array}$ \\
\hline R14 & $\begin{array}{l}\text { Sum of rainfall }\left(>0.25 \mathrm{~cm} \text { event } \mathrm{t}^{-1}\right) \text { over } \\
\text { preceding } 8 \text { cycles }\end{array}$ \\
\hline BIO & Biomass of live Spartina at creekside \\
\hline DERBIO & Derivative of BIO with respect to time \\
\hline FRESWTR & Freshwater flow during current cycle \\
\hline L1 FRESH & Freshwater flow during previous cycle \\
\hline L2 FRESH & $\begin{array}{l}\text { Freshwater flow during second previous } \\
\text { cycle }\end{array}$ \\
\hline AWTMP & Water temperature $-18.47^{a}$ \\
\hline WTMP2 & Square of water temperature \\
\hline LIGHT & Proportion of tidal cycle in daylight \\
\hline LIGHT2 & Square of LIGHT \\
\hline ALTWT & AWTMP $\times(\text { LIGHT }-0.5)^{\mathrm{b}}$ \\
\hline AWIND & Average wind speed $-8.76^{c}$ \\
\hline AWNDWT & AWIND $\times$ AWTMP \\
\hline AXWIND & Maximum wind speed \\
\hline AIRTMP & Air temperature less water temperature \\
\hline L100WT & $\begin{array}{l}\text { Water temperature for the } 100 \text { th previous } \\
\text { cycle }\end{array}$ \\
\hline L100WT2 & Square of L100WT \\
\hline \multicolumn{2}{|c|}{$\begin{array}{l}\text { a } 18.47=\text { average of water temperatures for sampled cycles } \\
\text { b (LIGHT }-0.5)=\text { average of a variable LIGHT for sampled } \\
\text { cycles }\end{array}$} \\
\hline \multicolumn{2}{|c|}{$\begin{array}{l}\text { c } 8.76=\text { average of average wind speeds for the sample } \\
\text { cycles }\end{array}$} \\
\hline
\end{tabular}

period between 19 June 1983 and 18 June 1984. During this time, there were 707 tidal cycles of which we sampled 34. To obtain monthly and annual flux estimates an initial stepwise regression was performed. This regression was used to select a smaller set $(<24)$ of predictor variables to be used in modelling the net flux/ cycle for each constituent. This subset of predictor variables was further refined by running all possible regressions and selecting the model that produced the minimum value of Mallows' Cp statistic (Mallows 1973). This model was used to form the regression estimate of the net flux on a monthly and an annual basis. The standard errors associated with the annual net flux estimates take into account the variability in net flux/ cycle estimates as well as the error in estimating the annual net flux from the 34 sampled cycles.

Annual nitrogen inputs into the Bly Creek basin via streamwater, groundwater, and rain were also estimated. Streamwater discharge measurements were made using a Parshall flume (1950) for the blackwater stream which enters the basin. In addition, nutrient concentrations in the streamwater were obtained by sampling 1 storm event per month. The storms were sampled once every $2 \mathrm{~h}$ for $2 \mathrm{~d}$. Since there was little variability in nutrient concentration throughout the period of an individual storm, the mean nutrient concentration per storm was multiplied by the monthly streamwater discharge to estimate the monthly nutrient input into the basin. The annual nutrient streamwater flux was obtained by summing monthly fluxes.

Groundwater flow within the basin was evaluated using a piezometric grid: 108 piezometers were inserted into the sediment of the Bly Creek basin at various depths and at specified stations along 3 transects. This configuration allowed for an evaluation of the direction and magnitude of groundwater movement throughout the basin. Water flow estimates were made by solving Darcy's equation using gradients in water table between the forested upland and the tidal creek and a tranmissivity of $30 \mathrm{~m}^{2}$ (Williams 1981). Nutrient concentrations were also measured in each of the piezometers every 2 mo throughout the sampling year. Groundwater flow was coupled with monthly mean nutrient content to estimate the monthly and eventual annual nitrogen flux into the tidal creek. Rainwater input to the Bly Creek basin was measured by the use of a weighing type recording rain gauge located $800 \mathrm{~m}$ west of the basin. Rainwater nitrogen concentrations were extracted from data collected on a separate project (conducted within a mile of the basin) whose duration overlapped the Bly Creek study. Water samples were taken for nitrogen analysis after each rain storm throughout the study period. Monthly nitrogen mean concentrations were crossed multiplied with monthly rainfall amount to estimate monthly nitrogen inputs into the basin via rainwater. Annual inputs were calculated summing the monthly fluxes.

\section{RESULTS AND DISCUSSION}

The most important aspect of any study of material flux through a tidal creek is the water budget due to its strong influence on material transport. The Bly Creek basin was chosen for this study since (1) it is confined on 3 sides by land and has only 1 tidal creek through which tidal water can flow into and out of the basin, and (2) the freshwater inputs to the basin could be estimated. In addition, the basin is shallow so at times it is nearly drained at low tide. This should ensure that water storage due to residual tidal flow, wind-drift, and estuarine storage/emptying (caused by the dynamic coupling to the coastal ocean) is minimal. The estimate of water flux through the tidal creek indicates there 
Table 2. Summary of annual fluxes $\left(\mathrm{kg} \mathrm{N} \mathrm{yr}^{-1} ;+\right.$ : export; - : import $)$

\begin{tabular}{|c|c|c|c|c|c|}
\hline & $\mathrm{H}_{2} \mathrm{O}\left(\mathrm{m}^{3} \mathrm{yr}^{-1}\right)$ & $\mathrm{NH}_{4}^{+}$ & $\mathrm{NO}_{3}{ }^{-}+\mathrm{NO}_{2}^{-}$ & DON & PN \\
\hline $\begin{array}{l}\text { Tidal creek } \\
\text { (SE) } \\
\text { Streamwater } \\
\text { Groundwater } \\
\text { Rainwater }\end{array}$ & $\begin{array}{r}1.15 \times 10^{7} \\
\left(8.01 \times 10^{6}\right) \\
-7.7 \times 10^{5} \\
-1.2 \times 10^{5} \\
-7.9 \times 10^{5}\end{array}$ & $\begin{array}{c}433 \\
(830) \\
-6.6 \\
-60.3 \\
-11.3\end{array}$ & $\begin{array}{c}-158.0 \\
(124) \\
-5.2 \\
-3.2 \\
-10.5\end{array}$ & $\begin{array}{l}7780 \\
(2460) \\
-892 \\
-152 \\
-189\end{array}$ & $\begin{array}{r}-1540 \\
(3670) \\
0.0 \\
0.0 \\
0.0\end{array}$ \\
\hline Net basin budget & $9.0 \times 10^{6}$ & 354 & -177 & 6550 & -1540 \\
\hline \multicolumn{6}{|c|}{ Vegetated salt marsh } \\
\hline \multicolumn{2}{|c|}{$\begin{array}{l}\text { Nitrogen export via runoff and seepage } \\
\text { during tidal exposure }\end{array}$} & 112 & 11 & 1660 & 1170 \\
\hline \multicolumn{2}{|c|}{ Oyster reef community } & 125 & 1 & -127 & -222 \\
\hline
\end{tabular}

was a small, though insignificant, export out of the basin of $1.15 \times 10^{7} \mathrm{~m}^{3} \mathrm{yr}^{-1}\left(\alpha=0.05, \mathrm{SE}=8.01 \times 10^{6}\right)$ On a per tidal cycle basis, this water export represents $2.4 \%$ of the tidal prism at basinful stage or $8.1 \%$ of the mean tidal prism.

In this study, we attempted to account for all the fluxes (except evapotranspiration) which may cause an imbalance of water flow at the transect. These include streamflow, groundwater flow, rainfall, storage effects, and sheetflow. The latter refers to water transport over the vegetated marsh and occurs when tidal water height is greater than bankful. Eiser \& Kjerfve (1986), after producing a detailed topographic map of the basin, showed that water storage in the basin at MLW ( $0.86 \mathrm{~m}$ above creek bottom at the BCT) was $2500 \mathrm{~m}^{3}$. The storage of tidal water within the basin during the sampling year was estimated by calculating the average difference between successive low tides for the 34 samplings. This value was only $0.01 \mathrm{~m}$ per tide, suggesting that storage effects in this system were negligible, as expected. Eiser \& Kjerfve (1986) also showed that sheetflow during a reasonably high tide was unimportant, but suggested that sheetflow could be important for high spring tides. An insignificant association between maximum high tide and the estimated import or export of water at the BCT suggests that this process has a negligible effect on net water transport. Finally, only $13 \%$ of the estimated water export from the basin can be accounted for by water inputs via streamwater, groundwater, and rain (Table 2). It is suggested that the point estimate of water export from this basin is due to sampling error since all the fluxes which account for this export were shown to be relatively insignificant.

Mean tidal $\mathrm{NH}_{4}{ }^{+}$concentrations varied seasonally between 1.0 and $10.4 \mu M \mathrm{~N}$ with higher values observed during late summer and early fall (Fig. 2A). The net $\mathrm{NH}_{4}{ }^{+}$flux data (Fig. 2B) suggest that there was an import to the basin during late summer and early fall and a general export from the basin throughout the rest of the year. The annual flux estimate indicated that the basin exported a statistically insignificant ( $\alpha=0.05)$ $433 \mathrm{~kg} \mathrm{~N}(\mathrm{SE}=830 \mathrm{~kg} \mathrm{~N})$ or $0.65 \mathrm{~g} \mathrm{~N} \mathrm{~m}^{-2} \mathrm{yr}^{-1}$. This
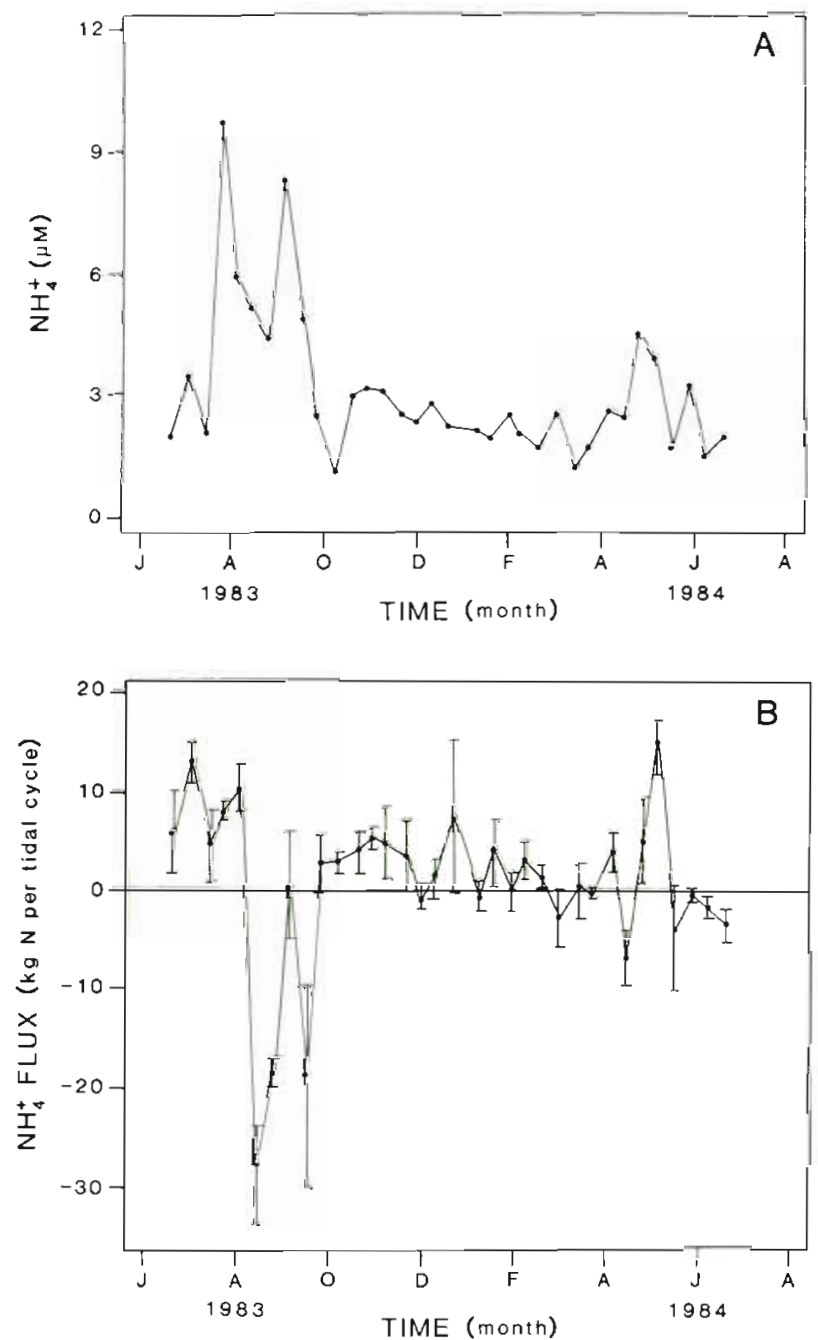

Fig. 2. (A) Mean tidal $\mathrm{NH}_{4}{ }^{+}$concentrations and (B) net $\mathrm{NH}_{4}{ }^{+}$ flux as a function of time of year (export + , import -) 
export value is in the lower range observed for the North Inlet system (Whiting et al. 1987) and other marsh-estuarine systems (Nixon 1980).

To determine the ammonium aqueous mass balance for the Bly Creek basin it is necessary to compare the tidally mediated export of this constituent from the basin with the inputs via streamwater, groundwater, and rain. The flux estimates in Table 2 suggest that inputs into the basin via streamwater, groundwater, and rain account for only a small percentage of the potential export from the basin through the tidal creek. However, it is difficult to state whether the basin is a source for $\mathrm{NH}_{4}{ }^{+}$because the tidally mediated export is not statistically significant $(\alpha=0.05)$.

Even though the Bly Creek system may not act as a sink or source for ammonium on an annual basis, there appears to be an active movement of ammonium within the basin. A study conducted to evaluate the nutrient processing role of the vegetated marsh surface (Whiting et al. unpubl.) suggests that this subsystem was a sink for ammonium throughout the year (ca $1500 \mathrm{~kg}$ $\mathrm{NH}_{4}{ }^{+}-\mathrm{N} \mathrm{Yr}^{-1}$; Table 2), especially during late summer and early fall. Since the flux estimates at the transect did not indicate a large import to the basin, there must be a source within the basin to supply the large input of $\mathrm{NH}_{4}{ }^{+}$to the vegetated marsh. The results from a nutrient exchange study on a oyster reef community within the basin (Dame et al. unpubl) did not show a large source of ammonium from this subsystem (Table 2). This would suggest the tidal creek water column and/or benthic community as the source of $\mathrm{NH}_{4}{ }^{+}$within the basin. Results from a number of recent studies (Agosta 1985, Jordan \& Correll 1985) indicate that seepage from creekbanks during low tide may contribute significant amounts of dissolved nutrients to the tidal creek. The advective movement of interstitial water from the creek bottom (Whiting \& Childers unpubl.) coupled with diffusion are possibly other major sources of nutrients (in this case, $\mathrm{NH}_{4}{ }^{+}$) to the creek water.

Mean tidal nitrate + nitrite $\left(\mathrm{NO}_{3}{ }^{-}+\mathrm{NO}_{2}{ }^{-}\right)$values varied from 0.1 to $2.1 \mu \mathrm{MN}$ (Fig. 3A). $\mathrm{High} \mathrm{NO}_{3}{ }^{-}+\mathrm{NO}_{2}{ }^{-}$ values were observed during August, September, and December and during spring. The $\mathrm{NO}_{3}{ }^{-}+\mathrm{NO}_{2}{ }^{-}$flux values (Fig. 3B) show a mixed trend with respect to transport direction: imports were observed during the spring, late summer, and early fall, and exports dominated the remainder of the year. On an annual basis there was a statistically insignificant $(\alpha=0.05) \mathrm{NO}_{3}{ }^{-}+$ $\mathrm{NO}_{2}{ }^{-}$import into the basin of $158 \mathrm{~kg} \mathrm{~N}(\mathrm{SE}=124 \mathrm{~kg} \mathrm{~N})$ or $0.23 \mathrm{~g} \mathrm{~N} \mathrm{~m}^{-2} \mathrm{yr}^{-1}$. This value is lower than most of the observed imports of this constituent into other marshestuarine system (Nixon 1980).

The aqueous $\mathrm{NO}_{3}{ }^{-}+\mathrm{NO}_{2}{ }^{-}$mass balance for the Bly Creek basin suggests this system is a sink for this
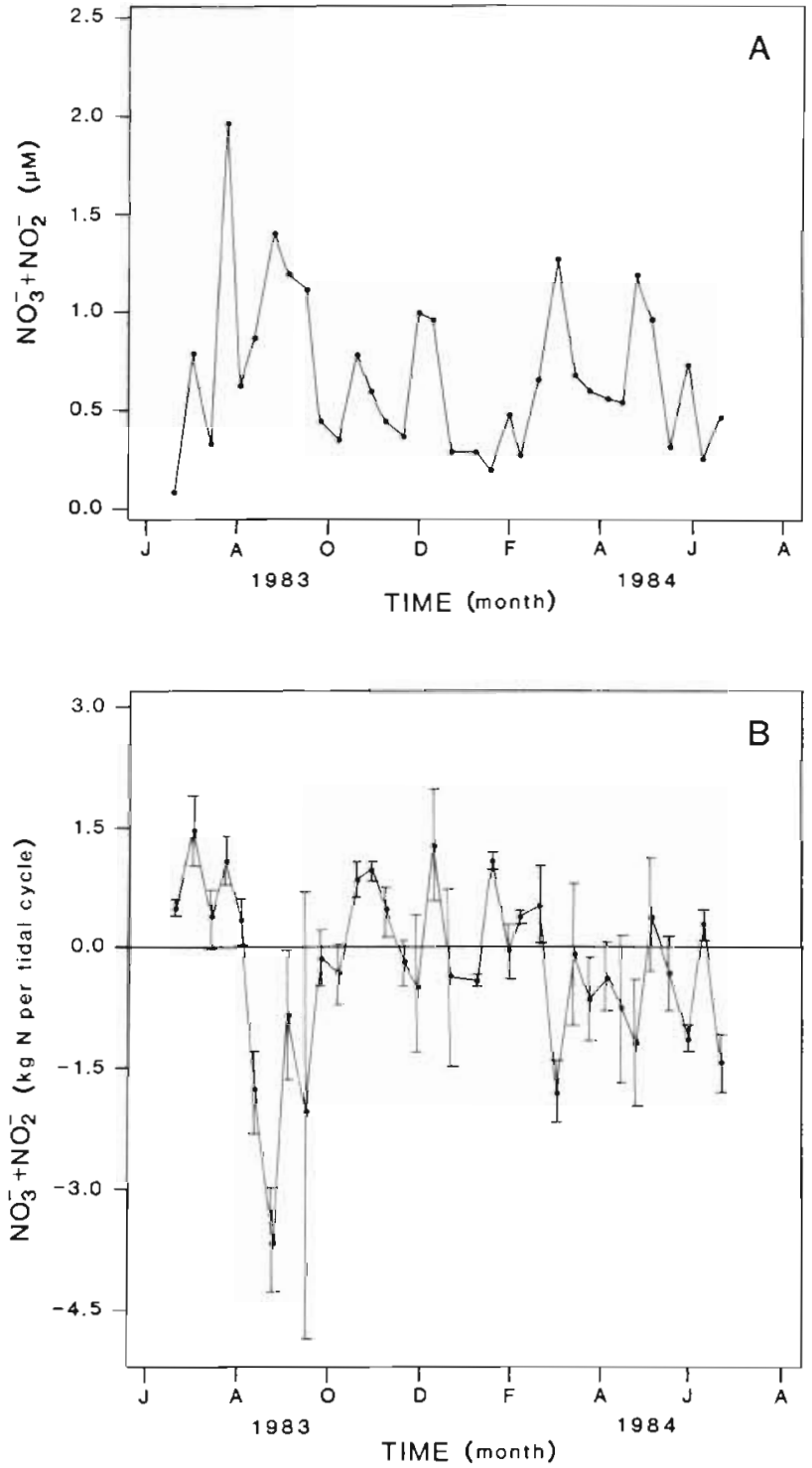

Fig. 3. (A) Mean tidal $\mathrm{NO}_{3}{ }^{-}+\mathrm{NO}_{2}{ }^{-}$(NN) concentrations, and (B) NN flux as a function of time of year (export + , import -)

constituent (Table 2). However, since the tidally mediated flux is not statistically significant, this assertion cannot be made with confidence. Within the basin, the vegetated marsh is capable of removing all the $\mathrm{NO}_{3}{ }^{-}+$ $\mathrm{NO}_{2}{ }^{-}$that was potentially imported into the basin via tidal exchange, streamwater, rainwater, and groundwater (Table 2). The results from the flume study on the oyster reef community show this subsystem contributes little to the cycling of $\mathrm{NO}_{3}{ }^{-}+\mathrm{NO}_{2}^{-}$within the basin (Dame et al. unpubl.).

Even though the vegetated marsh may remove all the $\mathrm{NO}_{3}^{-}+\mathrm{NO}_{2}^{-}$which is potentially imported into the basin, the tidal creek is not a passive conduit for this constituent. The dynamic activity of $\mathrm{NO}_{3}{ }^{-}+\mathrm{NO}_{2}{ }^{-}$ processing within the tidal creek is illustrated by its 
trend of concentration with time throughout the tidal cycle. Of 34 tidal cycles, 14 showed a maximum $\mathrm{NO}_{3}{ }^{-}$ $+\mathrm{NO}_{2}{ }^{-}$concentration at maximum flood and ebb discharge. This $\mathrm{NO}_{3}{ }^{-}+\mathrm{NO}_{2}{ }^{-}$concentration trend with time over a tidal cycle suggests that this constituent is possibly produced during periods of maximum water flow and turbulence. A positive association between water velocity and benthic respiration has been observed in a Maryland estuary (Boynton et al. 1981). It is suggested that $\mathrm{NO}_{3}{ }^{-}+\mathrm{NO}_{2}{ }^{-}$is produced in the water column by the oxidation of $\mathrm{NH}_{4}{ }^{+}$via nitrification. The $\mathrm{NO}_{3}{ }^{-}+\mathrm{NO}_{2}{ }^{-}$produced via this process is potentially removed from the tidal water within the tidal creek or as the water floods over the marsh surface. Nitrification within the tidal creek water was also suggested by Wolaver et al. (1984) as a possible source of $\mathrm{NO}_{3}{ }^{-}+\mathrm{NO}_{2}{ }^{-}$in another tidal creek in North Inlet.

Mean tidal DON concentrations varied between 11.2 and $34.7 \mu M N$ (Fig. $4 \mathrm{~A}$ ). The highest DON values were observed from March to July, which corresponds with the periods of streamflow for the small blackwater stream entering the basin. The relationship between DON concentration and tidal water salinity (Fig. 4B) supports this assertion since there is a negative association between these 2 variables when all the points which lie in the vicinity of 36 ppt salinity are omitted. DON concentrations within the blackwater stream reach $118 \mu M N$ during high flow conditions. However, there is another source of DON within the basin because high values of this constituent are also found at near seawater salinity. The source of this material could be either groundwater, export from the vegetated marsh during tidal inundation, runoff from the marsh during tidal exposure, or infiltration and commensurate seepage from the creek banks along the major tidal creeks. The net DON flux trend (Fig. 4C) suggests that DON was exported throughout the year. Annually there was a statistically significant ( $\alpha=0.05$ ) DON export from the basin of $7780 \mathrm{~kg} \mathrm{~N}$ (SE $=2460 \mathrm{~kg}$ $\left.\mathrm{N} \mathrm{yr}^{-1}\right)$. This annual export on an areal basis $(11.7 \mathrm{~g} \mathrm{~N}$ $\mathrm{m}^{-2} \mathrm{yr}^{-1}$ ) is slightly greater than the range observed for other marsh-estuarine systems (Nixon 1980).

The DON mass balance for the Bly Creek basin (Table 2) suggests that the sum of the inputs into the basin via streamwater, groundwater, and rain are not enough to account for the export of this constituent from the basin. This suggests that there must be a DON source within the basin. The flume study on the vegetated marsh shows that this subsystem acted as a DON source with a statistically significant export during tidal inundation $\left(3140 \mathrm{~kg} \mathrm{~N} \mathrm{Yr}^{-1}\right)$. If the value for DON export from the marsh via runoff and seepage during tidal exposure $\left(1660 \mathrm{~kg} \mathrm{~N} \mathrm{yr}^{-1}\right)$ is added to this, the total DON export from the marsh into the tidal creek will be even higher. The nutrient exchange study
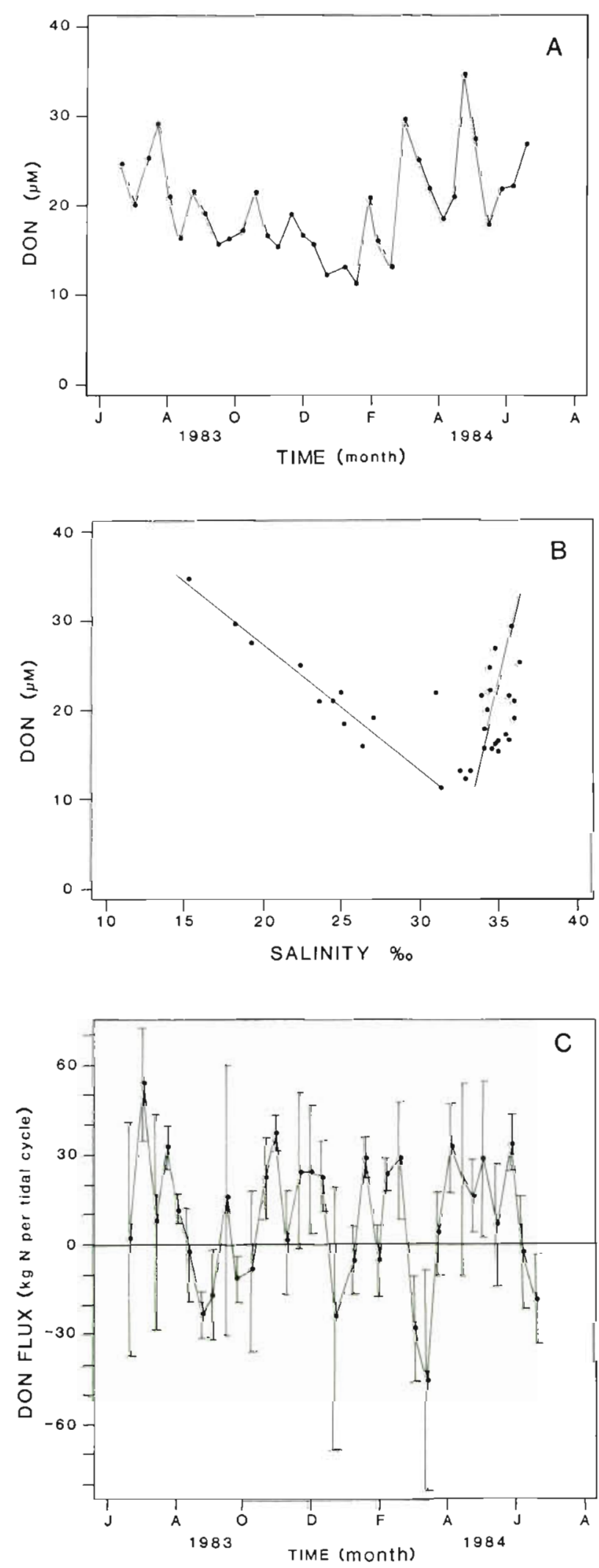

Fig. 4. (A) Mean tidal dissolved organic nitrogen (DON) concentrations as a function of time of year, and (B) tidal water salinity. (C) DON flux as a function of year (export + , import -) 
on the oyster reef community suggests that this subsystem imported $127 \mathrm{~kg} \mathrm{~N} \mathrm{yr}^{-1}$. This analysis indicates that the vegetated marsh could account for most of the DON exported from the basin.

Mean tidal particulate nitrogen (PN) concentrations varied seasonally between 3.7 and $35.2 \mu M N$ (Fig. 5A), with higher values observed during spring and summer. The highest values of PN were found just after a major storm passed through North Inlet $3.4 \mathrm{~cm}$ rain during low tide conditions). The similarity in trend of PN values and water temperature suggest that PN loads in the tidal water were caused by increased bioturbation and resuspension during the warmer months. The PN net flux data (Fig. 5B) indicate that during most of the year there was no net trend in flux direction through the tidal creek. However, during late summer and early fall when the tidal water had its highest PN load there was a net import into the basin. The annual flux estimate suggests that a statistically insignificant $(\alpha=0.05) 1540 \mathrm{~kg} \mathrm{~N}(\mathrm{SE}=3670 \mathrm{~kg} \mathrm{~N}$ $\mathrm{yr}^{-1}$ ) was imported into the Bly Creek basin. The magnitude of the PN flux on an areal basis $\left(2.3 \mathrm{~g} \mathrm{~N} \mathrm{~m}^{-2}\right.$ $\left.\mathrm{yr}^{-1}\right)$ is in the range of those found for other marshestuarine systems (Nixon 1980).

The Bly Creek basin is neither a sink nor a source for $\mathrm{PN}$ to the surrounding estuary since the nontidal inputs to the basin are negligible and the tidally mediated input to the basin is statistically insignificant (Table 2). Within the basin the vegetated marsh (Whiting et al. unpubl.) removed a statistically insignificant amount of $\mathrm{PN}$ and the oyster reef community removed only $233 \mathrm{~kg}$ $\mathrm{N} \mathrm{yr}^{-1}$ (Dame et al. unpubl.). However, a graph of PN flux through the tidal creek and maximum tidal height (Fig. 5C) suggests that when high tides were observed within the basin and a large percentage of the vegetated marsh was inundated there was an input of PN through the tidal creek. Therefore, it is proposed that the vegetated marsh can affect the PN transport direction and magnitude when high tide conditions prevail.

Marsh-estuarine systems along the eastern coast of the USA have been shown to export $\mathrm{NH}_{4}{ }^{+}, \mathrm{DON}$, and $\mathrm{PN}$, and import $\mathrm{NO}_{3}{ }^{-}$. These results led Nixon (1980) to suggest that marshes import dissolved oxidized nitrogen and export reduced dissolved and particulate forms. The Bly Creek Ecosystem Study supports these trends, with the obvious exception that this system potentially imported PN. Even though the tidal creek has not been seen as a passive conduit, the vegetated marsh has long been thought to be the site which controlled the trends discussed above.

Significant rates of denitrification and $\mathrm{N}_{2}$-fixation within the vegetated marsh have led to the assumption that these processes were responsible for the import of $\mathrm{NO}_{3}{ }^{-}$and export of $\mathrm{NH}_{4}{ }^{+}$found in most of the nitrogen exchange studies in tidal creeks (Nixon 1980). How-
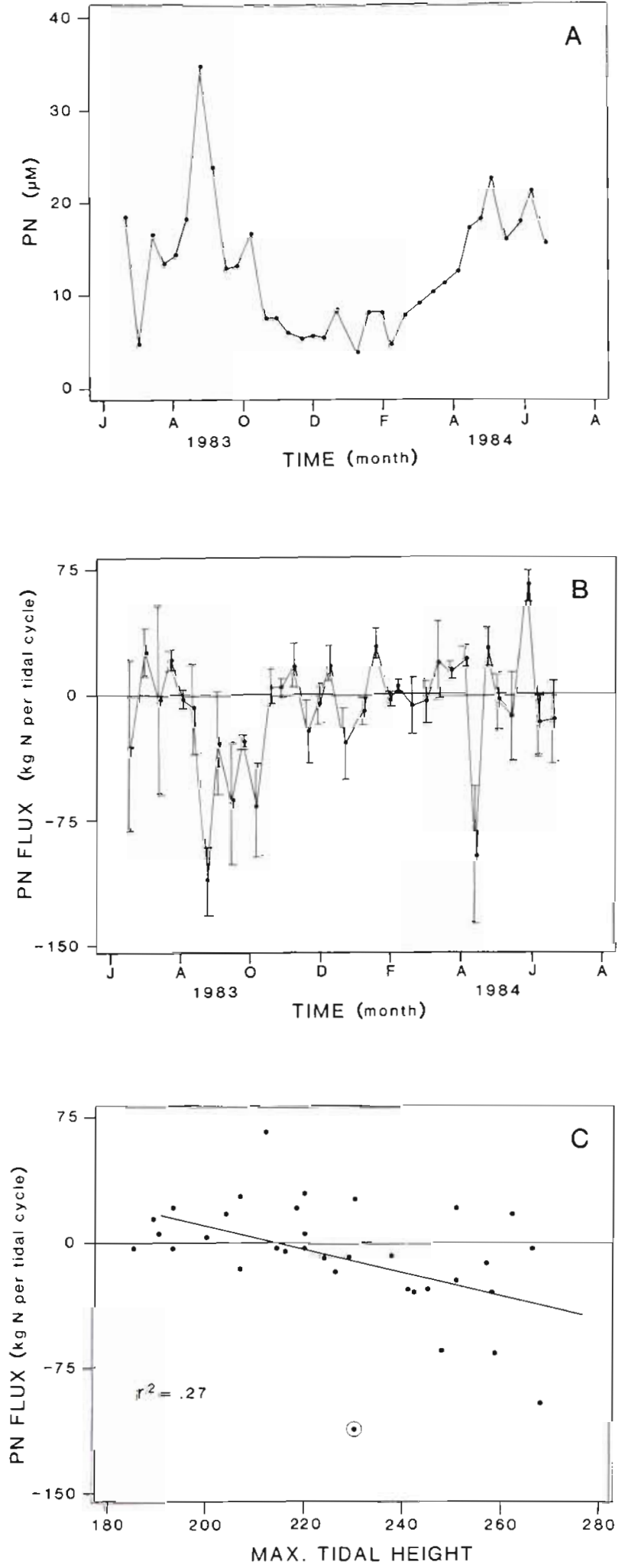

Fig. 5. (A) Mean tidal particulate nitrogen (PN) concentrations, and (B) PN flux as a function of time of year (export + , import -). (C) Net PN flux as a function of maximum tidal height (export + , import - ; circled data point omitted from regression analysis) 
ever, flume studies on vegetated marshes in both mesohaline and euhaline (Bly Creek study site) systems suggest that this subsystem is a sink for $\mathrm{NH}_{4}{ }^{+}$. The $\mathrm{NH}_{4}{ }^{+}$flux data from the Bly Creek study indicate that the tidal creek subsystem produced the $\mathrm{NH}_{4}{ }^{+}$ which was both potentially exported from the basin and removed as tidal water resided on the marsh surface. It is hypothesized that the tidal creek water column coupled to the benthic substrate is heterotrophic with a net remobilization of $\mathrm{NH}_{4}{ }^{+} . \mathrm{NH}_{4}{ }^{+}$may be produced by (1) heterotrophic utilization of particulates and/or dissolved organics, and/or (2) phytoplanktonic excretion. This study does support the contention that the vegetated marsh is the sink for the $\mathrm{NO}_{3}{ }^{-}+\mathrm{NO}_{2}{ }^{-}$ imported in this and possibly other tidal creek systems. The vegetated marsh within the Bly Creek basin was capable of removing all the $\mathrm{NO}_{3}{ }^{-}+\mathrm{NO}_{2}{ }^{-}$that was potentially imported into the basin via the tidal creek, streamwater, groundwater, and rain. However, the tidal creek was shown not to be an inactive conduit for this constituent. It is hypothesized that active cycling of $\mathrm{NO}_{3}{ }^{-}$occurs within the tidal creek water column, with $\mathrm{NO}_{3}{ }^{-}$formed via nitrification.

The origin of outwelled dissolved organics has been attributed to processes occurring on the vegetated marsh surface such as leaching from live and dead Spartina (Turner 1978, Pakulski 1986) or diffusion from marsh sediments (Pomeroy et al. 1977). Correspondingly, the source of the outwelled PN was assumed to be associated with marsh macrophyte productivity (Valiela et al. 1978). This study supports the assertion that the vegetated marsh may be an important source of DON which is outwelled in this system (Whiting et al. unpubl.) and possibly other marsh-estuarine systems. In addition, it appears that a significant percentage of the DON exported from this basin entered the basin via the blackwater stream. This DON had its source in litter decomposition within the maritime forest (Wolaver \& Williams 1986). The Bly Creek PN flux data suggest that the vegetated marsh has a strong effect on the flux direction and magnitude of this constituent through the tidal creek during high tide conditions. It appears that normally there was a PN export through the tidal creek, especially if the maximum tidal height was lower than $230 \mathrm{~cm}$ (Fig. 5C). This can be explained by asymmetries in velocity and discharge magnitude as a function of time over a tidal cycle. In this system maximum water velocity and discharge were always observed on the ebbing tide. In addition, maximum flood and ebb water velocity and discharge occurred just before and just after high slack tide. The observed asymmetry in magnitude and timing of maximum water velocity and discharge suggests that there should normally be an export of particulates through the tidal creek (Boon 1975). However, the effect of the marsh surface on removing particulate material from the tidal water was strong enough to counter this trend when a large percentage of the marsh was inundated.

In summary, the Bly Creek Ecosystem Study showed that the movement of nitrogen through the Bly Creek basin is quite complicated and may be controlled by chemical, physical, hydrodynamic (asymmetries in tidal velocity and discharge), and biological processes. Evidence suggests that the tidal creek subsystem is where reduced particulate and dissolved organic species are processed. These materials enter the tidal creek from either the adjacent marsh or are transported into the basin through the tidal creek. The by-products of decomposition, especially $\mathrm{NH}_{4}{ }^{+}$, are released into the tidal creek water column with the possible production of nitrate via nitrification. Most of this material is then transported back onto the vegetated marsh surface on the flood tide where it is utilized.

Acknowledgements. These data were collected with the help of an interdisciplinary research group supported by NSF grant DEB 8119752 . Special thanks to Steve Hutchinson, Malcolm Mitchell, Bob McLaughlin, Helen Tarbox, and Anne Miller for their technical assistance.

\section{LITERATURE CITED}

Agosta, K. A. (1985). The effect of tidally induced changes in the creek bank water table on pore water chemistry. Estuar. coast. Shelf Sci. 21: $381-400$

Axelrad, D. M. (1974). Nutrient flux through the salt marsh ecosystem. Ph. D. thesis, College of William and Mary, Gloucester Point, Va.

Boon, J. D. (1975). Tidal discharge asymmetry in a salt marsh drainage system. Limnol. Oceanogr 20:71-80

Boynton, W. R., Kemp, W. M., Osborne, C. G., Kaumeyer, K. R., Jenkins, M. C. (1981). Influence of water cirulation rate on in situ measurements of benthic community respiration. Mar. Biol. 65: 185-190

Chrzanowski, T H., Stevenson, L. H., Spurrier, J. C. (1982). Transport of particulate organic carbon through the North Inlet Ecosystem. Mar. Ecol. Prog. Ser 7: 231-245

Dame, R. F. Wolaver, T G., Libes, S. M. (1985). The summer uptake and release of nitrogen by an intertidal oyster reef. Neth. J. Sea Res. 19(314): 265-268

Dame, R., Chrzanowski, T. H., Bildstein, K., Kjerfve, B., McKellar, H., Nelson, D., Spurrier, J., Stancyk, S., Stevenson, H., Vernberg, J., Zingmark, R. (1986). The outwelling hypothesis and North Inlet, South Carolina. Mar. Ecol. Prog. Ser, 33: 217-229

Eiser, W. C., Kjerfe, B. (1986). Marsh topography and hypsometric characteristics of a South Carolina salt marsh basin. Estuar, coast. Shelf Sci. 23: 595-605

Gallagher, J. L., Pfeiffer, W. J., Pomeroy, L. R. (1976). Leaching and microbial utilization of dissolved organic carbon from leaves of Spartina alterniflora. Estuar. coast. mar. Sci. 4: $467-471$

Glibert, P. M., D'Elia, F. S., Mlodzinsky, L. (1977). A semiautomated persulfate oxidation technique for simultaneous total nitrogen and total phosphorus determination in natural water samples. In: Glibert, P., Lowder, T. C. (eds.) 
Automated analysis of nutrients in seawater: a manual of techniques. Woods Hole Oceanographic Institution, Contribution 3954, Woods Hole, Massachusetts, USA

Heinle, D. R., Flemer, D. A. (1976). Flows of materials between pourly flooded tidal marshes and an estuary. Mar. Biol. 35: 359-373

Jordan, T E., Correll, D. L. (1985). Nutrient chemistry and hydrology of interstitial water in brackish tidal marshes of Chesapeake Bay. Estuar, coast. Shelf Sci. 21: 45-55

Kjerfve, B. (1982). Calibration of estuarine current crosses. Estuar. coast. Shelf Sci. 15: 553-559

Kjerfve, B., Stevenson, L. H, Proehl, J. A., Chrzanowski, T. H., Kitchens, W. M. (1981). Estimation of material fluxes in an estuarine cross section: a critical analysis of spatial measureent density and errors. Limnol. Oceanogr. 26: 325-335

Kjerfve, B., Wolaver, T. G. (1988). Sampling optimization for studies of tidal transport in estuaries. Trans. Am. Fish. Soc. 3: $26-33$

Mallows, C. L. (1973). Some comments on Cp. Technometrics 15: $661-675$

Nixon, S. W (1980). Between coastal marshes and coastal waters - a review of twenty years of speculation and research in the role of salt marshes in estuarine productivity and water chemistry. In: Hamilton, P., McDonald, K. B. (eds.) Estuarine and wetland processes. Plenum Publ. Corp., New York, p. 437-525

O'Brien, J., Fiore, J. (1962). Ammonia determination by automated analysis. Wastes Eng. 33: 352

Odum, E. P. (1968). A research challenge: evaluating the productivity of coastal and estuarine water. In: Keiffner, E. (ed.) Proceedings of the Second Sea Grant Conference, Univ. of Rhode Island, October 1968. Newport, Rhode Island, USA, p. 63-64

Pakulski, J. D. (1986). The release of reducing sugars and dissolved organic carbon from Spartina alterniflora Loisel in a Georgia salt marsh. Estuar. coast. Shelf Sci. 22: 385-394

Parshall, R. L. (1950). Measuring water in irrigation channels with Parshall flumes and small weirs. US Soil Conservation Service Circular 843. U.S. Dept of Agriculture, Government Printing Office, Washington, D.C

Pomeroy, L. R., Bancroft, K., Breed, J., Christian, R. R., Frankenberg, D., Hall, J. R., Maurer, L. G., Wiebe, W. J., Wiegert, R. G., Wetzel, R. L. (1977). Flux of organic matter through a salt marsh. In: Wiley, M. (ed.) Estuarine processes, Vol. 2. Academic Press, New York, p. 270-279

Teal, J. M. (1962). Energy flow in the salt marsh ecosystem of Georgia. Ecology 43: 614-624

Turner, R. E. (1978). Community plankton respiration in a salt marsh estuary and the importance of macrophyte leacheates. Limnol. Oceanogr. 23: 442-451

Valiela, I., Teal, J. M., Volkonan, S., Shafer, D., Carpenter, E. J. (1978). Nutrient and particulate fluxes in salt marsh ecosystems: tidal exchanges and inputs by precipitation and groundwater. Limnol. Oceanogr. 3: 798-812

Whiting, G. J., McKellar, H. N., Kjerfve, B., Spurrier, J. D. (1985). Sampling and computational design of nutrient flux from a southeastern U. S. saltmarsh. Estuar. coast. Shelf Sci. 21: 273-286

Whiting, G. J, McKellar, H. N., Kjerfve, B., Spurrier, J. D. (1987). Nitrogen exchange between a southeastern USA salt marsh ecosystem and the coastal ocean. Mar. Biol. 95: $173-182$

Williams, T. M. (1981). Determinations of transmissivity of shallow aquifers on high water table forested area by pumping tests. Forest Sci. 27: 124-127

Wolaver, I G., Johnson, W., Marozas, M. (1984). Nitrogen and phosphorus concentrations within North Inlet, South Carolina - speculation as to sources and sinks. Estuar. coast. Shelf Sci. 19: 243-255

Wolaver, T G., Whiting, G., Kjerfve, B., McKellar, H., Zingmark R, Dame, R., Chrzanowski, T., Spurrier, J., Williams, $T$ (1985). The flume design - a methodology for evaluating material fluxes between a vegetated salt marsh and the adjacent tidal creek. J. exp. mar Biol. Ecol. 91: 281-291

Wolaver, T G., Williams, T M. (1986). Streamwater chemistry of a small forested watershed on the South Carolina coast. Southeast. Geol. 27(1): 45-51

Wolaver, T G., Zieman, J. (1984). The role of the tall and medium Spartina alterniflora zones in the processing of nutrients in tidal water. Estuar. coast. Shelf Sci. 19: 1-13

Wolaver, T G., Zieman, J., Wetzel, R., Webb, K. (1983). Nitrogen and phosphorus exchange between a mesohaline vegetated marsh and the adjacent estuary. Estuar. coast. Shelf Sci. 16: 321-332

Woodwell, G. M., Hall, C. A. S., Whitney, D. E., Houghton, R. A. (1979). The Flax pond ecosystems study; exchanges of inorganic nitrogen between an estuarine marsh and Long Island Sound. Ecology 60: 695-702 